\title{
Paper
}

\section{Preparation of (W, Mo)C-SiC Ceramics and their Mechanical Properties}

\author{
Chao Liu ${ }^{\text {के } 1}$, Akihiro Nino ${ }^{\text {के }}$, Shigeaki Sugiyama ${ }^{\text {क } 2}$ and Hitoshi Taimatsu ${ }^{\text {के } 1}$ \\ $\leqslant 1$ Department of Materials Science and Engineering, Graduate School of Engineering and Resource Science, Akita University, \\ 1-1 Tegata-Gakuenmachi, Akita 010-8502, Japan. \\ ${ }^{2}$ Akita Prefectural Research and Development Center, 4-11 Sanuki, Araya, Akita 010-1623, Japan.
}

Received May 11, 2012

\begin{abstract}
SYNOPSIS
Binderless cemented carbides consisting of a $(\mathrm{W}, \mathrm{Mo}) \mathrm{C}$ solid solution and $\mathrm{SiC}$ were synthesized and consolidated by resistance-heated hot pressing of $\mathrm{WC}-\mathrm{Mo}_{2} \mathrm{C}-\mathrm{C}-\mathrm{SiC}$ powder mixtures in the temperature range of 1600 to $1800^{\circ} \mathrm{C}$. The microstructures and reaction products of the ceramics were examined, and their density and mechanical properties were measured. The solid-state reaction for synthesizing $(\mathrm{W}, \mathrm{Mo}) \mathrm{C}$ solid solutions is $(1-x) \mathrm{WC}+x / 2$ $\mathrm{Mo}_{2} \mathrm{C}+x / 2 \mathrm{C} \rightarrow \mathrm{W}_{1-x} \mathrm{Mo}_{x} \mathrm{C}$. Without the addition of $\mathrm{SiC}, \mathrm{Mo}_{2} \mathrm{C}$ remained after hot pressing. However, for (W, Mo)C-SiC ceramics obtained from the powder mixtures with $\mathrm{SiC}$ content $\geq 5$ mol\% and $x \leq 0.2$, very little residual $\mathrm{Mo}_{2} \mathrm{C}$ was observed. Each $(\mathrm{W}, \mathrm{Mo}) \mathrm{C}$ grain was composed of a $\mathrm{W}$-rich core phase and a $\mathrm{W}$-deficient phase on the core's periphery, suggesting a two-phase separation during cooling. The (W,Mo)C-SiC ceramics with $x \leq 0.2$ were densely sintered, and their Young's modulus changed with the SiC content according to the Voigt mixture rule. The $(\mathrm{W}, \mathrm{Mo}) \mathrm{C}-\mathrm{SiC}$ ceramics sintered at $1600^{\circ} \mathrm{C}$ had high hardness above $23 \mathrm{GPa}$ and a fracture toughness of $\sim 5.8 \mathrm{MPa} \mathrm{m}^{1 / 2}$.
\end{abstract}

KEY WORDS

tungsten carbide, molybdenum monocarbide, silicon carbide, reactive hot pressing, mechanical properties

\section{Introduction}

Binderless (without metallic binders) cemented carbides, in which tungsten carbide (WC) is an essential material, have been used as glass-lens-forming dies and hard corrosion-resistant parts due to their excellent properties, including hardness, elasticity, thermal conductivity, and chemical stability. Kanemitsu et al. ${ }^{10}$ first developed a WC$\mathrm{TaC}-\mathrm{TiC}$ binderless cemented carbide. Since then, WC$\mathrm{SiC}$ ceramics have been examined in detail for their sintering and mechanical properties ${ }^{2-4)}$. However, the increasing demand and limited supply of tungsten have prompted the use of larger amounts of other carbides. We recently tried to manufacture dense ceramics composed of $\mathrm{WC}-\mathrm{MoC}$ solid solutions ((W, Mo) C) using reactive resistance-heated hot pressing (spark-plasma sintering) of $\mathrm{WC}-\mathrm{Mo}_{2} \mathrm{C}-\mathrm{C}$ powder mixtures to replace $\mathrm{WC}$ with $\mathrm{MoC}^{5 \text { ) }}$. Residual $\mathrm{Mo}_{2} \mathrm{C}$ remained after hot pressing at $1700^{\circ} \mathrm{C}$. (W, Mo)C solid solutions ( $<20 \mathrm{~mol} \% \mathrm{MoC})$ were produced by annealing the hot-pressed samples at $2000^{\circ} \mathrm{C}$. The $\mathrm{SiC}$ addition in WC enhanced the sintering reaction, resulting in significant WC grain growth ${ }^{2-4)}$. This indicates that atomic migration in the bulk or at the interface of WC grains becomes more active due to $\mathrm{SiC}$. Preliminary experiments showed that the $\mathrm{SiC}$ addition in $\mathrm{WC}-\mathrm{Mo}_{2} \mathrm{C}-\mathrm{C}$ powder mixtures accelerated the $\mathrm{W}_{1-x} \mathrm{Mo}_{x} \mathrm{C}$ formation reaction and enabled the preparation of dense $(\mathrm{W}, \mathrm{Mo}) \mathrm{C}-\mathrm{SiC}$ ceramics with only reactive hot pressing. Although (W, Mo) C ceramics have been synthesized for almost 30 years ${ }^{6.7)}$, there has been little research done on their manufacturing method, microstructure, or mechanical properties for practical use.

The purpose of this study was to examine the amount of $\mathrm{SiC}$ required and the sintering conditions needed to prepare dense (W, Mo) C-SiC ceramics. The ceramics were synthesized and simultaneously consolidated by reactive resistance-heated hot-pressing of $\mathrm{WC}-\mathrm{Mo}_{2} \mathrm{C}-\mathrm{C}-\mathrm{SiC}$ powder mixtures. The reaction products, microstructures, density, and mechanical properties were examined.

\section{Experimental}

WC powders (Japan New Metals, average particle diameter $0.73 \mu \mathrm{m}$, chemical composition (mass\%): total carbon 6.13, free carbon 0.02, Fe 0.05, Mo 0.02), $\beta$-SiC (Yakushima Denko, average particle diameter $0.60 \mu \mathrm{m}$, impurities (mass\%): free carbon 0.85, $\mathrm{Fe} 0.015, \mathrm{Al} 0.012$, $\mathrm{SiO}_{2} 0.30$ ), $\mathrm{Mo}_{2} \mathrm{C}$ (Japan New Metals, average particle diameter $1.57 \mu \mathrm{m}$, chemical composition (mass \%): total 
carbon 5.95, free carbon 0.11 , Co 0.08 ), and carbon black (Mitsubishi Chemical, Ketjenblack EC600JD) were used as the starting materials to produce $\mathrm{W}_{1-x} \mathrm{Mo}_{x} \mathrm{C}$ by the solidstate reaction

$$
(1-x) \mathrm{WC}+\frac{x}{2} \mathrm{Mo}_{2} \mathrm{C}+\frac{x}{2} \mathrm{C} \rightarrow \mathrm{W}_{1-x} \mathrm{Mo}_{x} \mathrm{C}
$$

during hot pressing. The experimental procedure was described in detail in a previous paper ${ }^{5)}$ and is briefly described here. Weighed powders for targeted chemical compositions of $\mathrm{W}_{0.8} \mathrm{Mo}_{0.2} \mathrm{C}-\mathrm{SiC}(0-30 \mathrm{~mol} \% \mathrm{SiC})$ and $\mathrm{W}_{1-x}$ $\mathrm{Mo}_{x} \mathrm{C}-20 \mathrm{~mol} \% \mathrm{SiC}(x=0-0.30)$ were mixed in ethanol with WC-8 mass\% Co balls in a nylon pot for $24 \mathrm{~h}$. Each powder mixture was sintered in the temperature range of $1600-1800^{\circ} \mathrm{C}$ with a resistance-heated hot-pressing machine (Sumitomo Coal Mines, Spark-Plasma Sintering Machine SPS-2080). The density was measured by the Archimedean method. The reaction products were analyzed with a powder X-ray diffractometer (XRD, Rigaku, RINT2500VHF). The microstructure was evaluated with an electron microanalyzer (EPMA, JEOL, JXA-8230). Young's modulus was determined by the pulse-echo method with a high-temperature elastodynamic rate-measuring system (Toshiba Tungalloy, UMS-HL). Vickers hardness tests were carried out under a $9.8 \mathrm{~N}$ load. The fracture toughness was estimated by the indentation method using Evans and Davis's equation ${ }^{8,9)}$.

\section{Results and Discussion}

\subsection{Reaction products and microstructure}

For targeted $\mathrm{W}_{0.8} \mathrm{Mo}_{0.2} \mathrm{C}-\mathrm{SiC}$ composition, residual $\mathrm{Mo}_{2} \mathrm{C}$ always remained after hot pressing, without the addition of $\mathrm{SiC}$. Above $5 \mathrm{~mol} \% \mathrm{SiC}$, however, $\mathrm{Mo}_{2} \mathrm{C}$ had almost disappeared entirely after hot pressing. Small amounts of the $\mathrm{Mo}_{5} \mathrm{Si}_{3} \mathrm{C}$-type structure (Nowotny phase, JCPDS pattern No.43-1199 of $\mathrm{Mo}_{4.8} \mathrm{Si}_{3} \mathrm{C}_{0.6}{ }^{10)}$ ) were detected in ceramics containing $\mathrm{SiC}$ as a reaction product. EPMA analysis indicated that the compound contained $\mathrm{W}$, in addition to $\mathrm{Mo}, \mathrm{Si}$, and $\mathrm{C}$, verifying the Nowotny phase (W,Mo $)_{5} \mathrm{Si}_{3} \mathrm{C}^{11}$. Figure 1 shows the relative intensity of $\mathrm{Mo}_{2} \mathrm{C}$ and Nowotny-phase-type (W, Mo $)_{5} \mathrm{Si}_{3} \mathrm{C}$ in the ceramics. The relative intensity was calculated from the maximum peak intensities of $\mathrm{W}_{1-\chi} \mathrm{Mo}_{x} \mathrm{C}, \mathrm{Mo}_{2} \mathrm{C}$, and/or (W,Mo $)_{5} \mathrm{Si}_{3} \mathrm{C}$ detected in the ceramics. The $\mathrm{Mo}_{2} \mathrm{C}$ residue was attributed to incomplete development of the reaction given in Eq. (1). When unreacted $\mathrm{Mo}_{2} \mathrm{C}$ remains in the ceramic, the reaction products must contain residual carbon. However, very small amounts of carbon (graphite) were detected by XRD only for $\mathrm{W}_{0.7} \mathrm{Mo}_{0.3} \mathrm{C}-20 \mathrm{~mol} \% \mathrm{SiC}$, which contained considerable amounts of $\mathrm{Mo}_{2} \mathrm{C}$ and $\mathrm{C}$ in the starting powder.

When fine WC powder was hot-pressed, small amounts of hemicarbide $\left(\mathrm{W}_{2} \mathrm{C}\right)$ formed in the sintered ceramics ${ }^{2.12)}$. Small amounts of $\mathrm{W}_{5} \mathrm{Si}_{3}$ were found after hot pressing fine powder mixtures containing $\mathrm{WC}$ and $\mathrm{SiC}^{2,4)}$. These products are produced by surface oxidation of the starting fine WC powder: $7(5) \mathrm{WC}+\mathrm{WO}_{3}\left(\mathrm{WO}_{2}\right) \rightarrow 4(3) \mathrm{W}_{2} \mathrm{C}+$ $6(2) \mathrm{CO}$ for the $\mathrm{W}_{2} \mathrm{C}$ formation and $3(7) \mathrm{WC}+3(8) \mathrm{SiC}+$ $2 \mathrm{WO}_{3}\left(8 \mathrm{WO}_{2}\right) \rightarrow 1(3) \mathrm{W}_{5} \mathrm{Si}_{3}+6(16) \mathrm{CO}$ for $\mathrm{W}_{5} \mathrm{Si}_{3}$ formation, where the values in parentheses correspond to the reaction for $\mathrm{WO}_{2}$. Consequently, the formation of small amounts of the low carbon compound (W,Mo $)_{5} \mathrm{Si}_{3} \mathrm{C}$ were attributed to the same cause.

When $\mathrm{SiC}$ was not added to the powdered mixture, unreacted $\mathrm{Mo}_{2} \mathrm{C}$ remained after hot pressing. For $\mathrm{SiC}$ addition $\geq 5 \mathrm{~mol} \%$, small amounts of residual $\mathrm{Mo}_{2} \mathrm{C}$ were evident. For $\mathrm{W}_{0.7} \mathrm{Mo}_{0.3} \mathrm{C}-20 \mathrm{~mol} \% \mathrm{SiC}$, with the addition of considerable amounts of $\mathrm{Mo}_{2} \mathrm{C}$ and $\mathrm{C}$, however, unreacted $\mathrm{Mo}_{2} \mathrm{C}$ remained. Ceramics composed of $(\mathrm{W}, \mathrm{Mo}) \mathrm{C}-\mathrm{SiC}$ were obtained for $x \leq 0.2$ and $\mathrm{SiC}$ content $\geq 5 \mathrm{~mol} \%$.

Figure 2 shows the microstructure of $\mathrm{W}_{0.8} \mathrm{Mo}_{0.2} \mathrm{C}-20$ $\mathrm{mol} \% \mathrm{SiC}$ and $\mathrm{W}_{0.7} \mathrm{Mo}_{0.3} \mathrm{C}-20 \mathrm{~mol} \% \mathrm{SiC}$. The $\mathrm{W}_{0.8} \mathrm{Mo}_{0.2} \mathrm{C}-$ $20 \mathrm{~mol} \% \mathrm{SiC}$ was composed of black, scattered $\mathrm{SiC}$ grains and a (W, Mo) C solid solution matrix. For $\mathrm{W}_{0.7} \mathrm{Mo}_{0.3} \mathrm{C}-20$ mol\% $\mathrm{SiC}$, dark $\mathrm{Mo}_{2} \mathrm{C}$ grains were also found, consistent with the XRD results. Each (W, Mo) C grain was not compositionally homogeneous. Since no dissolution of $\mathrm{SiC}$ in the $(\mathrm{W}, \mathrm{Mo}) \mathrm{C}$ phase was detected by EPMA, the $\mathrm{W}_{1-x}$ $\mathrm{Mo}_{x} \mathrm{C}-\mathrm{SiC}$ system is the same as the $\mathrm{W}_{1-x} \mathrm{Mo}_{x} \mathrm{C}$ system for
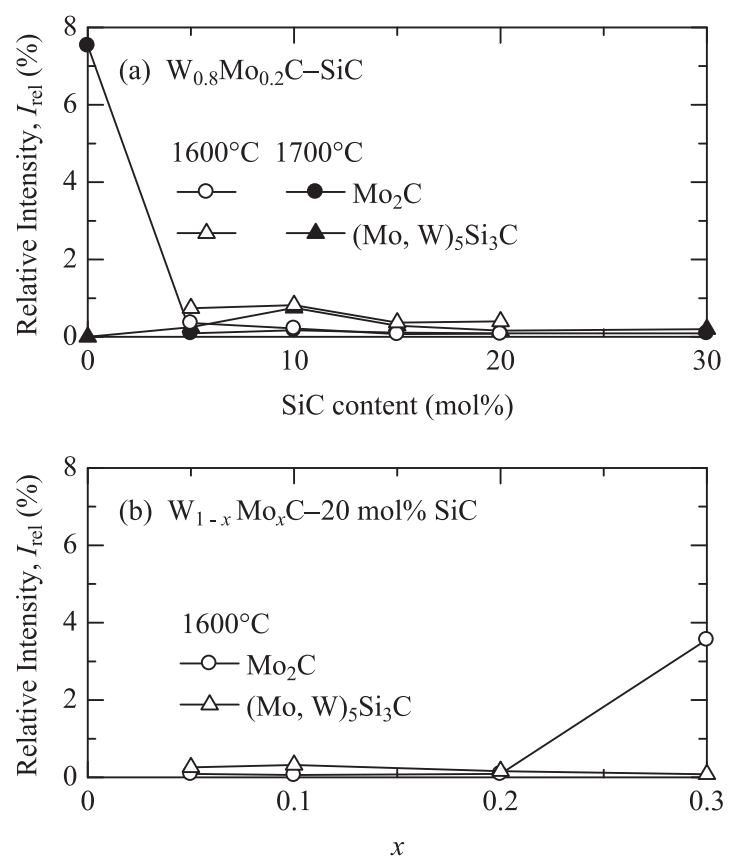

Fig. 1 Relative intensity of $\mathrm{Mo}_{2} \mathrm{C}$ and $(\mathrm{W}, \mathrm{Mo})_{5} \mathrm{Si}_{3} \mathrm{C}$. 

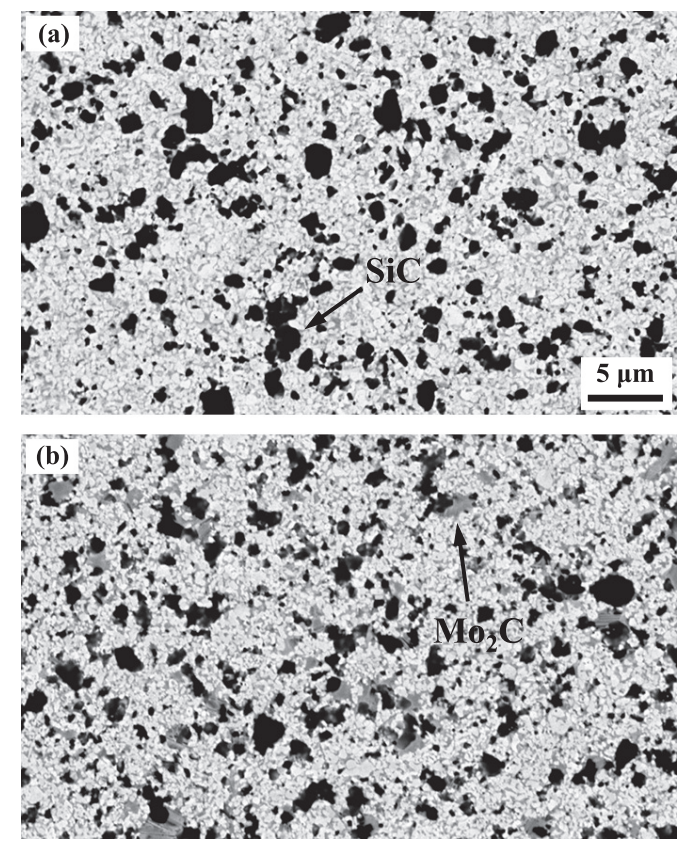

Fig. 2 Microstructures of the ceramics: (a) $\mathrm{W}_{0.8} \mathrm{Mo}_{0.2} \mathrm{C}-20 \mathrm{~mol} \%$ $\mathrm{SiC}$ and (b) $\mathrm{W}_{0.7} \mathrm{Mo}_{0.3} \mathrm{C}-20 \mathrm{~mol} \% \mathrm{SiC}$ (backscattered electron images).

phase equilibrium in a (W, Mo) $\mathrm{C}$ grain. In the $\mathrm{W}_{1-x} \mathrm{Mo}_{x} \mathrm{C}$ system examined in our previous study ${ }^{5}$, every $(\mathrm{W}, \mathrm{Mo}) \mathrm{C}$ grain was composed of a $\mathrm{W}$-rich core phase $\left(\mathrm{W}_{0.92-0.98}\right.$ $\left.\mathrm{Mo}_{0.08-0.06} \mathrm{C}\right)$ and a peripheral $\mathrm{W}$-deficient phase $\left(\mathrm{W}_{0.52-0.56}\right.$ $\left.\mathrm{Mo}_{0.48-0.44} \mathrm{C}\right)$ and that the $\mathrm{W}$-rich core phase was precipitated in the $(\mathrm{W}, \mathrm{Mo}) \mathrm{C}$ grain. Figure 3 shows the structural change in $\mathrm{W}_{1-x} \mathrm{Mo}_{x} \mathrm{C}-20 \mathrm{~mol} \% \mathrm{SiC}$ with increasing $x$. The transmission electron microscope observation and analysis in the previous study ${ }^{5}$ strongly indicated that the core structure was formed by a two-phase separation during cooling; such a region is not shown in the calculated WCMoC phase diagram ${ }^{13,14)}$. Considering the results of the previous study ${ }^{5)}$, a continuous $\mathrm{W}$-rich phase $(\mathrm{W}, \mathrm{Mo}) \mathrm{C}$ was obtained for $x<0.06$; the two-phase region composed of W-rich and W-deficient (W,Mo) C phases was obtained for $x=0.06-0.48$.

\subsection{Density}

Dense ceramics were produced at $\mathrm{SiC}$ addition $\geq 5 \mathrm{~mol} \%$. Figure 4 shows the bulk density in the $\mathrm{W}_{1-x} \mathrm{Mo}_{x} \mathrm{C}-20$ mol\% $\mathrm{SiC}$ and $\mathrm{W}_{0.8} \mathrm{Mo}_{0.2} \mathrm{C}-\mathrm{SiC}$ systems. The calculated lines in the figure used the density values of $\mathrm{W}_{1-x} \mathrm{Mo}_{x} \mathrm{C}$ determined from lattice parameters in our previous study ${ }^{5}$ and $\beta-\mathrm{SiC}$ $\left(3.216 \times 10^{3} \mathrm{~kg} \mathrm{~m}^{-3}\right)^{13}$. Every measured value fell on the lines, except for $\mathrm{W}_{0.7} \mathrm{Mo}_{0.3} \mathrm{C}-20 \mathrm{~mol} \% \mathrm{SiC} . \mathrm{W}_{0.7} \mathrm{Mo}_{0.3} \mathrm{C}-$ $20 \mathrm{~mol} \% \mathrm{SiC}$ had residual $\mathrm{Mo}_{2} \mathrm{C}$ and $\mathrm{C}$. The low densities of the residual $\mathrm{Mo}_{2} \mathrm{C}$ and $\mathrm{C}$ decreased the density of the resulting ceramic, which was lower compared with
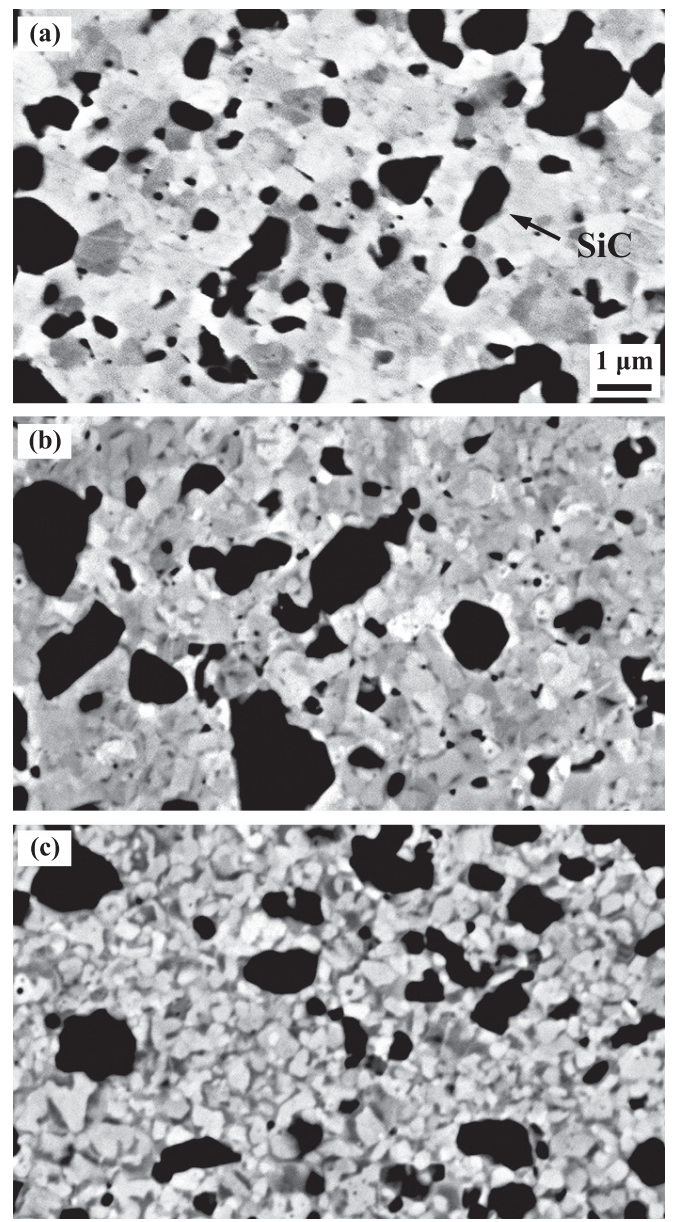

Fig. 3 Change in the microstructure with $x$ in the $\mathrm{W}_{1-x} \mathrm{Mo}_{x} \mathrm{C}-20$ mol\% SiC ceramics: (a) $x=0.05$, (b) $x=0.1$, and (c) $x=0.2$ (backscattered electron images).

ceramics composed only of the $\mathrm{W}_{1-x} \mathrm{Mo}_{x} \mathrm{C}$ and $\mathrm{SiC}$ phases. 3.3 Mechanical properties

Figure 5 shows the Young's modulus in the $\mathrm{W}_{0.8} \mathrm{Mo}_{0.2} \mathrm{C}$ $\mathrm{SiC}$ and $\mathrm{W}_{1-x} \mathrm{Mo}_{x} \mathrm{C}-20 \mathrm{~mol} \% \mathrm{SiC}$ systems. The calculated line in Fig. 5 (a) was obtained using the Voigt mixture rule, $E=E_{\mathrm{W} 0.8 \mathrm{M} 00.2} V_{\mathrm{W} 0.8 \mathrm{M} 00.2}+E_{\mathrm{SiC}} V_{\mathrm{SiC}}$, where $E, E_{\mathrm{W} 0.8 \mathrm{M} 00.2}$, and $E_{\mathrm{SiC}}$ are the Young's modulus of the mixture, $\mathrm{W}_{0.8} \mathrm{Mo}_{0.2} \mathrm{C}$ (this study $660 \mathrm{GPa}$ ), and $\beta-\mathrm{SiC}$ (hot-pressed $\beta-\mathrm{SiC} 440 \mathrm{GPa}^{17}$ ), respectively, and $V_{\mathrm{w} 0.8 \mathrm{M} 0.2 .2}$ and $V_{\mathrm{SiC}}$ are the volume fraction of the $\mathrm{W}_{0.8} \mathrm{Mo}_{0.2} \mathrm{C}$ and $\mathrm{SiC}$ phases, respectively. The volume fraction was calculated from the density of $\beta$-SiC and the measured density of $\mathrm{W}_{0.8} \mathrm{Mo}_{0.2} \mathrm{C}$ shown in Fig. 4. As is widely known, the Voigt model is derived by assuming that the constituents exhibit the same strain under a constant applied stress. The measured Young's modulus in $\mathrm{W}_{0.8} \mathrm{Mo}_{0.2} \mathrm{C}$ $\mathrm{SiC}$ was very close to the calculated value.

The Young's modulus in the $\mathrm{W}_{1-x} \mathrm{Mo}_{x} \mathrm{C}-20 \mathrm{~mol} \% \mathrm{SiC}$ system decreased slightly with increasing $x$ (for $x<0.2$ ), and the reduction became larger for $x \geq 0.2 . \quad \mathrm{W}_{0.7} \mathrm{Mo}_{0.3} \mathrm{C}$ - 

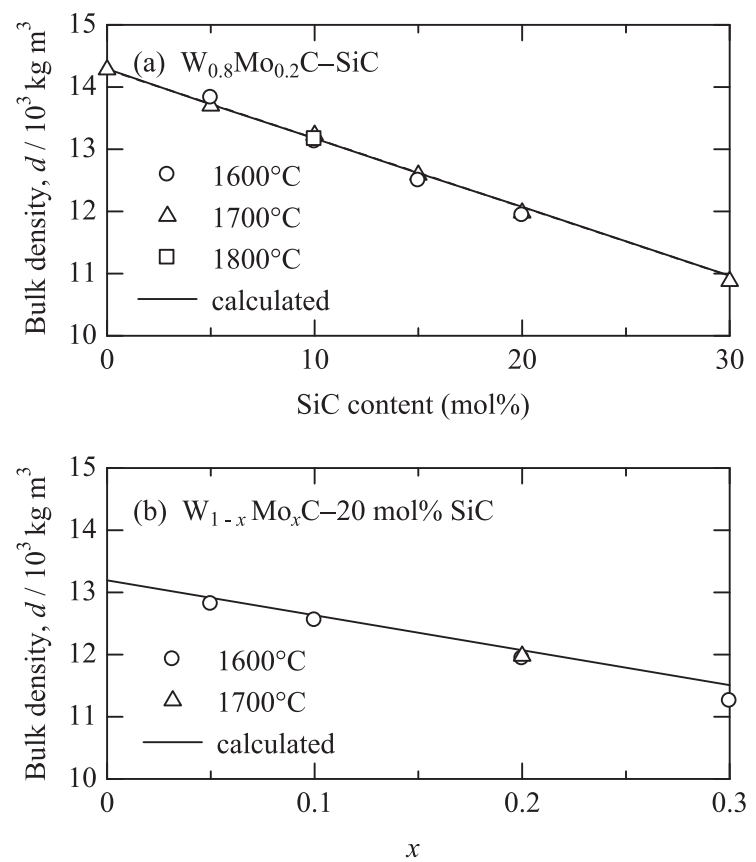

Fig. 4 Bulk density of the ceramics: (a) $\mathrm{W}_{0.8} \mathrm{Mo}_{0.2} \mathrm{C}-\mathrm{SiC}$ and (b) $\mathrm{W}_{1-x} \mathrm{Mo}_{x} \mathrm{C}-20 \mathrm{~mol} \% \mathrm{SiC}$.
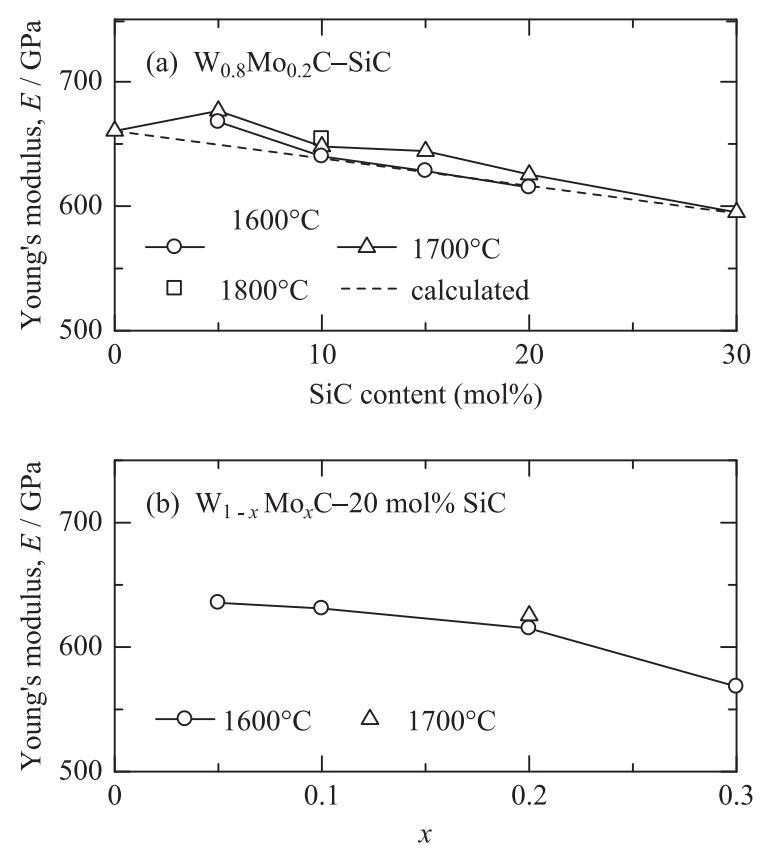

Fig. 5 Young's modulus of the ceramics: (a) $\mathrm{W}_{0.8} \mathrm{Mo}_{0.2} \mathrm{C}-\mathrm{SiC}$ and (b) $\mathrm{W}_{1-x} \mathrm{Mo}_{x} \mathrm{C}-20 \mathrm{~mol} \% \mathrm{SiC}$.

$20 \mathrm{~mol} \% \mathrm{SiC}$ had residual $\mathrm{Mo}_{2} \mathrm{C}$ and $\mathrm{C}$. The decrease in the Young's modulus suggests that this was due to the residual $\mathrm{Mo}_{2} \mathrm{C}$ and $\mathrm{C}$. The Young's modulus of a hot-pressed $\mathrm{Mo}_{2} \mathrm{C}$ was reported to be $400 \mathrm{GPa}^{18)}$, which is lower than that of the hot-pressed $\beta$-SiC $(440 \mathrm{GPa})^{17)}$.

Figure 6 shows the Vickers hardness in the $\mathrm{W}_{0.8} \mathrm{Mo}_{0.2} \mathrm{C}-$ $\mathrm{SiC}$ and $\mathrm{W}_{1-x} \mathrm{Mo}_{x} \mathrm{C}-20 \mathrm{~mol} \% \mathrm{SiC}$ systems. The $\mathrm{SiC}$ addition
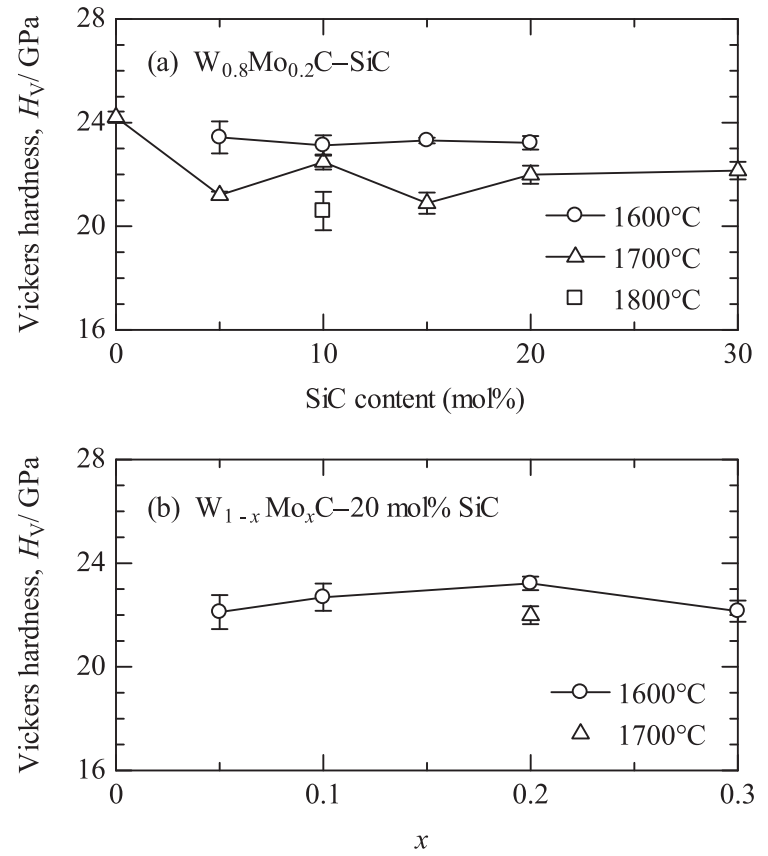

Fig. 6 Vickers hardness of the ceramics: (a) $\mathrm{W}_{0.8} \mathrm{Mo}_{0.2} \mathrm{C}-\mathrm{SiC}$ and (b) $\mathrm{W}_{1-x} \mathrm{Mo}_{x} \mathrm{C}-20 \mathrm{~mol} \% \mathrm{SiC}$.
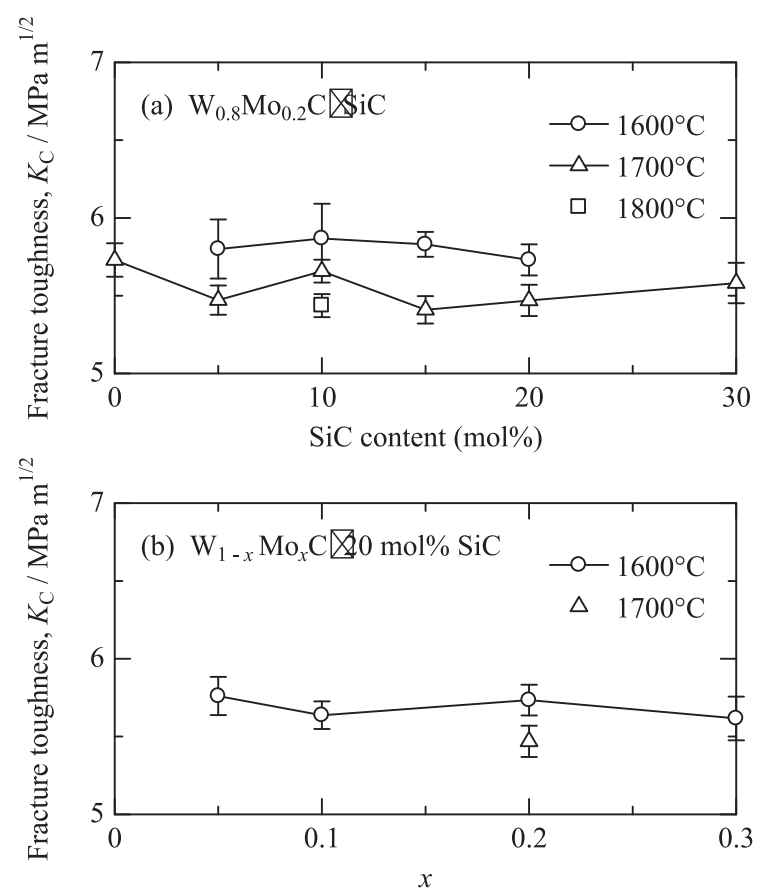

Fig. 7 Fracture toughness of the ceramics: (a) $\mathrm{W}_{0.8} \mathrm{Mo}_{0.2} \mathrm{C}-\mathrm{SiC}$ and (b) $\mathrm{W}_{1-x} \mathrm{Mo}_{x} \mathrm{C}-20 \mathrm{~mol} \% \mathrm{SiC}$.

did not significantly decrease the hardness; there was little change in the hardness in the range of 5 to $30 \mathrm{~mol} \%$. Increasing the sintering temperature decreased the hardness; this was due to the growth of (W,Mo)C grains. The ceramics sintered at $1600^{\circ} \mathrm{C}$ showed high hardness values, $\sim 23 \mathrm{GPa}$.

Figure 7 shows the fracture toughness in the $\mathrm{W}_{0.8} \mathrm{Mo}_{0.2} \mathrm{C}-$ $\mathrm{SiC}$ and $\mathrm{W}_{1-x} \mathrm{Mo}_{x} \mathrm{C}-20$ mol\% SiC. The SiC addition and 
the increase in $x$ hardly influenced the fracture toughness. Raising the sintering temperature lowered the fracture toughness and hardness (Fig. 6). Consequently, the ceramics with higher hardness exhibited higher fracture toughness, contrary to the common inverse relation between hardness and fracture toughness (i.e., the higher the hardness, the lower the fracture toughness). Similar results were obtained in (W, Mo) C ceramics reported in the previous paper ${ }^{5)}$. Hence, the (W, Mo) C phase undoubtedly caused this phenomenon; however, the reason was not clarified in this study.

\section{Summary}

Synthesis of $(\mathrm{W}, \mathrm{Mo}) \mathrm{C}-\mathrm{SiC}$ ceramics from $\mathrm{WC}-\mathrm{Mo}_{2} \mathrm{C}-$ $\mathrm{C}-\mathrm{SiC}$ powder mixtures, which lead to the solid-state reaction for synthesizing $(\mathrm{W}, \mathrm{Mo}) \mathrm{C}$ solid solutions, $(1-x)$ $\mathrm{WC}+x / 2 \mathrm{Mo}_{2} \mathrm{C}+x / 2 \mathrm{C} \rightarrow \mathrm{W}_{1-x} \mathrm{Mo}_{x} \mathrm{C}$, and their simultaneous consolidation were performed by reactive resistance-heated hot pressing in the sintering temperature range of 1600 to $1800^{\circ} \mathrm{C}$. Without the addition of $\mathrm{SiC}$, unreacted $\mathrm{Mo}_{2} \mathrm{C}$ remained after hot pressing. Above $5 \mathrm{~mol} \% \mathrm{SiC}$ for $x \leq$ 0.2 , only a very small amount of $\mathrm{Mo}_{2} \mathrm{C}$ was evident. Each (W,Mo)C grain in the ceramics with $x \geq 0.1$ was composed of a $\mathrm{W}$-rich core phase and a $\mathrm{W}$-deficient phase on the core periphery; for $x \leq 0.05$, this core structure was hardly visible. Dense ceramics were obtained for $\mathrm{SiC}$ addition $\geq$ 5 mol\% and $x \leq 0.2$, in good agreement with density calculations. The Young's modulus of the $\mathrm{W}_{0.8} \mathrm{Mo}_{0.2} \mathrm{C}-$ $\mathrm{SiC}$ ceramics obeyed the Voigt mixture rule. $(\mathrm{W}, \mathrm{Mo}) \mathrm{C}$ $\mathrm{SiC}$ ceramics sintered at $1600^{\circ} \mathrm{C}$ showed high hardness values above $23 \mathrm{GPa}$. The ceramics with higher hardness exhibited higher fracture toughness.

\section{References}

1) Y. Kanemitsu, T. Nishimura, H. Yoshino, K. Takao, and Y. Masumoto: "Effect of Hot Isostatic Pressing on Binderless Cemented Carbide", Refract. Met. Hard Mater., 1(1982)66-68.

2) S. Sugiyama, D. Kudo, and H. Taimatsu: "Preparation of WC-SiC Whisker Composites by Hot Pressing and their Mechanical Properties", Mater. Trans., 49(2008) 1644-1649.

3) H. Taimatsu, S. Sugiyama, and M. Komatsu: "Effect of $\mathrm{Cr}_{3} \mathrm{C}_{2}$ and $\mathrm{V}_{8} \mathrm{C}_{7}$ on the Microstructure and Mechanical Properties of WC-SiC Whisker Ceramics", Mater. Trans., 50(2009) 2435-2440.

4) A. Nino, Y. Nakaibayashi, S. Sugiyama, and H.
Taimatsu: "Microstructure and Mechanical Properties of WC-SiC Composites", Mater. Trans., 52(2011) 1641-1645.

5) C. Liu, M. Komatsu, A. Nino, S. Sugiyama, and H. Taimatsu: "Preparation of WC-MoC Ceramics and their Mechanical Properties", J. Jpn. Soc. Powder Powder Metallurgy, 59(2012)479-483.

6) S.W.H. Yih, S.A. Worcester Jr., and E. Rudy: "Cemented Carbides Containing Hexagonal Molybdenum", US Pat., 4049380, (1977).

7) E. Rudy, B.F. Kieffer, and E. Baroch: "Hafnium Nitride Coatings for Cemented Carbides, and New HardFacing Alloys on the Basis of $(\mathrm{Mo}, \mathrm{W}) \mathrm{C}-(\mathrm{Mo}, \mathrm{W})_{2} \mathrm{C}$ ", Planseeber. Pulvermetall., 26(1978) 105-117.

8) C.B. Ponton and R.D. Rawlings: "Vickers Indentation Fracture Toughness Test Part 1, Review of Literature and Formulation of Standardized Indentation Toughness Equations", Mater. Sci. Technol., 5(1989)865-872.

9) C.B. Ponton and R.D. Rawlings: "Vickers Indentation Fracture Toughness Test Part 2, Application and Critical Evaluation of Standardised Indentation Toughness Equations", Mater. Sci. Technol., 5(1989)961-976.

10) Powder Diffraction File, JCPDS-International Center for Diffraction Data, Pennsylvania, (2002) No.43-1199.

11) B.A. Gnesin and P.A. Gurzhiyants: "Refsicoat Heat Resistant Material and High-Temperature Electric Heaters Using Said Material", US Pat. 6770856, (2004).

12) J. Zhao, T. Holland, C. Unuvar, and Z. A. Munir: "Sparking Plasma Sintering of Nanometric Tungsten Carbide", Int. J. Refract. Met. Hard Mater., 27(2009) 130-139.

13) G.J. Throop, P. Rogl, and R. Rudy: "Calculation of Phase Equiliburia in Ternary System", High Temp. High Pressures, 10(1978)553-559.

14) P. Gustafson: "A Thermodynamic Evaluation of the C-Mo-W System", Z. Metallkd., 79(1988)397-402.

15) Powder Diffraction File, JCPDS-International Center for Diffraction Data, Pennsylvania, (2002) No. 291129.

16) R. Riedel: Handbook of Ceramic Hard Materials, Wiley-VCH, (2000)71-72.

17) T.D. Gulden: "Mechanical Properties of Polycrystalline $\beta$-SiC", J. Am. Ceram. Soc., 52(1969)585-590.

18) A. Nino, A. Tanaka, S. Sugiyama and H. Taimatsu: "Indentation Size Effect for the Hardness of Refractory Carbides", Mater. Trans., 51(2010)1621-1626. 